\title{
Recovery of Struvite from Synthetic Animal Wastewater by Continuous Reaction Crystallization Process
}

\author{
Anna Kozik, Nina Hutnik, Boguslawa Wierzbowska, Krzysztof Piotrowski, and Andrzej Matynia
}

\begin{abstract}
Experimental results concerning continuous process of phosphate $(V)$ ions recovery from synthetic animal breeding wastewater were presented. It was concluded, that phosphate(V) ions precipitated as sparingly soluble salts: amorphous calcium phosphate( $(V)$ (above $70 \%$ in a product) and struvite (below 30\%). Solid product contained also impurities, mainly in the form of co-precipitated sparingly soluble metal hydroxides. Product size did not exceed $80 \mu \mathrm{m}$. Its mean size varied from ca. 15 to ca. $18 \mu \mathrm{m}$. Population homogeneity was moderate, with high agglomeration effects. Excess of magnesium ions in relation to phosphate $(V)$ ions concentration (molar ratio $1.2: 1)$ in a feed influenced process course and its results advantageously. Struvite content in a product increased more than $20 \%$. Product size also enlarged - mean size was ca. $17 \%$ larger.
\end{abstract}

Index Terms-Struvite, synthetic animal breeding wastewater, continuous reaction crystallization, DT MSMPR crystallizer, product quality, phosphorus recycling.

\section{INTRODUCTION}

Animal breeding wastewaters, especially liquid manure, are recently regarded as inexpensive and easily accessible secondary sources of phosphorus compounds [1]. Depending on a given wastewater origin, its collection method and even storage conditions the phosphorus content varies from 0.2 to 0.4 mass $\%$ on the average. Recovery of phosphate( $\mathrm{V})$ ions from animal breeding wastewater is a complex process, difficult in practical implementation [2], [3], mainly because of its chemical composition. Main problem is high nitrogen, potassium and calcium contents, similar to phosphorus content [4], as well as presence of other impurities (especially: zinc, manganese, boron, copper and iron). These can catalyse or inhibit nucleation of struvite, calcium phosphates(V) and other sparingly soluble salts or/and hydroxides, as well as influence further nuclei growth, thus product quality [5].

Struvite $\left(\mathrm{MgNH}_{4} \mathrm{PO}_{4} \cdot 6 \mathrm{H}_{2} \mathrm{O}\right.$, MAP) precipitates after contacting magnesium (e.g. magnesium chloride) and ammonium ions with aqueous solution containing phosphate $(\mathrm{V})$ ions and alkalisation of the resulting mixture (7

Manuscript received March 27, 2015; revised May 22, 2015. This work was supported by the Ministry of Science and Higher Education of Poland within a frame of statutory activity grant realized in Faculty of Chemistry, Wroclaw University of Technology.

A. Kozik, N. Hutnik, B. Wierzbowska, and A. Matynia are with the Faculty of Chemistry, Wroclaw University of Technology, Wroclaw, Poland (e-mail:

anna.kozik@pwr.edu.pl,nina.hutnik@pwr.edu.pl, boguslawa.wierzbowska $@$ pwr.edu.pl, andrzej.matynia@pwr.edu.pl).

K. Piotrowski is with Department of Chemical Engineering and Process Design, Silesian University of Technology, Gliwice, Poland (e-mail: krzysztof.piotrowski@polsl.pl).
$<\mathrm{pH}<11$ ) [6]. In presence of calcium ions also calcium phosphates(V) precipitate. Depending on the process parameters (mainly $\mathrm{pH}$ ) and solution composition various crystalline or amorphous phases can form: $\mathrm{CaHPO}_{4} \cdot 2 \mathrm{H}_{2} \mathrm{O}$ (brushite, DCPD), $\quad \mathrm{Ca}_{4} \mathrm{H}\left(\mathrm{PO}_{4}\right)_{3} \cdot 2,5 \mathrm{H}_{2} \mathrm{O} \quad$ (OCP), $\mathrm{Ca}_{3}\left(\mathrm{PO}_{4}\right)_{2} \cdot n \mathrm{H}_{2} \mathrm{O}$ (ACP or TCP, $n$ can be also 0), $\mathrm{Ca}_{5}\left(\mathrm{PO}_{4}\right)_{3} \mathrm{OH}$ (hydroxyapatite, HAP) and others [7]. Presence of calcium ions in a process system results that the product is a mixture of struvite and calcium phosphates(V) [8]. It essentially restricts its possible application as a mineral fertilizer [9].

The research results concerning continuous struvite reaction crystallization process from synthetic animal breeding wastewater (SABW), of chemical composition similar to liquid cattle manure, are compared [1], [4]. Concentration of phosphate(V) ions in this solution was 0.208 mass \%. Crystallizer was provided with a feed assuming molar ratio $\mathrm{PO}_{4}{ }^{3-}: \mathrm{Mg}^{2+}$ as $1: 1$ (stoichiometric conditions) and $1: 1.2$ (magnesium ions excess related to phosphate(V) ions concentration in struvite synthesis reaction). Process ran at $\mathrm{pH} 9$ in temperature $298 \mathrm{~K}$. Mean residence time of suspension in a crystallizer was $3600 \mathrm{~s}$. Chemical and phase compositions of the resulting products, solids size distributions, as well as their statistical parameters were determined.

\section{MATERIALS AND METHODS}

\section{A. Setup and Procedure}

Experimental tests ran in a continuous laboratory DT MSMPR (Draft Tube, Mixed Suspension Mixed Product Removal) type crystallizer with internal circulation of suspension forced by propeller stirrer. Photo of experimental stand is presented in Fig. 1. It was fully automated Mettler Toledo plant. Steering, control and acquisition of measurement data were done with the use of PC computer (software: iControl LabMax 4.0). Crystallizer's working volume was $V_{\mathrm{w}} 0.6 \mathrm{dm}^{3}$ (total volume $V_{\mathrm{t}} 2 \mathrm{dm}^{3}$ ). Crystallizer (redesigned automatic reactor LabMax Mettler Toledo), made of glass, was equipped with heating/cooling coil for temperature stabilisation, as well as with a system supplying the compressed air required for both $\mathrm{CO}_{2}$ stripping and oxidation of organic substances present in the struvite reaction crystallization environment. Crystallizer's main dimensions were as follows: diameter $d 100 \mathrm{~mm}$, working part's height $h_{\mathrm{w}} 70 \mathrm{~mm}$, total height $h_{\mathrm{t}} 200 \mathrm{~mm}$. Inside the crystallizer circulation profile (DT, $d_{\mathrm{dt}} 54 \mathrm{~mm}, h_{\mathrm{dt}} 45 \mathrm{~mm}$ ) was installed where four-paddle propeller stirrer of diameter $d_{\mathrm{m}} 46$ $\mathrm{mm}$ operated. Mixer speed, temperature, stream of the 
compressed air, inlet streams of feed and alkalising solution, as well as outflow of product crystals suspension were strictly controlled and adjusted by computer.

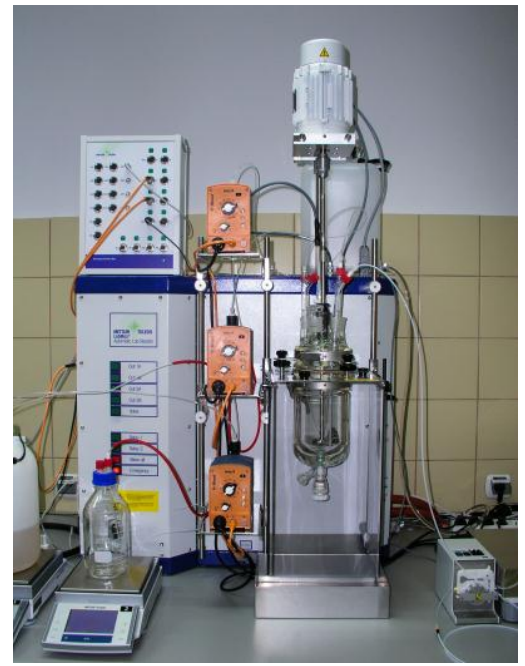

Fig. 1. Photo of experimental plant - continuous reaction crystallization of struvite (Mettler Toledo).

Crystallizer was continuously provided with a feed represented by aqueous solution of synthetic animal breeding wastewater and magnesium ions - substrates in struvite reaction crystallization process. The solution was prepared in external mixer applying the following crystalline substances: $\mathrm{NH}_{4} \mathrm{H}_{2} \mathrm{PO}_{4}, \quad \mathrm{MgCl}_{2} \cdot 6 \mathrm{H}_{2} \mathrm{O}, \mathrm{NH}_{4} \mathrm{Cl}, \mathrm{KCl}, \mathrm{NaCl}, \mathrm{CaCl}_{2}$, $\mathrm{CuCl}_{2} \cdot 2 \mathrm{H}_{2} \mathrm{O}, \quad \mathrm{MnCl}_{2} \cdot 4 \mathrm{H}_{2} \mathrm{O}, \quad \mathrm{ZnCl}_{2}, \quad \mathrm{CoCl}_{2} \cdot 6 \mathrm{H}_{2} \mathrm{O}$ and $\mathrm{FeCl}_{3} \cdot 6 \mathrm{H}_{2} \mathrm{O}$ (reagents purity, POCh, Gliwice, Poland), standard solutions of $\mathrm{H}_{3} \mathrm{BO}_{3}$ and $\left(\mathrm{NH}_{4}\right)_{6} \mathrm{Mo}_{7} \mathrm{O}_{24}$ (CertiPUR, Merck, Germany) and deionised water (Barnstead-NANOpure DIamond). Detailed chemical composition of the feed is presented in Table I. The solution (feed) was continuously provided into draft tube (DT) subvolume (mixer speed: $4.0 \quad 1 / \mathrm{s}$; suspension flow downward). Between the crystallizer body and DT element (suspension movement - upward) aqueous 3 mass \% solution of $\mathrm{NaOH}$ was dosed in amount providing the assumed, controlled $\mathrm{pH}$ value ( $\mathrm{pH}$ 9). Research ran in temperature 298 K. Feed flow was $0.6 \mathrm{dm}^{3} / \mathrm{h}$, what resulted from the assumed mean residence time of suspension in a crystallizer (3600 s). Compressed air flow was $100 \mathrm{Ndm}^{3} / \mathrm{h}$ (pressure ca. 2.5 bar). After stabilization in a crystallizer of the required parameter values, process in a steady state ran through the equivalent of 5 mean residence times of suspension in a crystallizer (here: 5 h). After this time solid phase content in suspension $\left(M_{\mathrm{T}}\right)$ was determined with analytical methods. Solid phase, separated on vacuum filter from mother solution, was not washed with water but dried in atmospheric air in ambient temperature.

\section{B. Analytical Methods}

Chemical compositions of mother liquor and solid product were determined with atomic absorption spectrometer iCE 3000 (metals), spectrophotometer UV-VIS Evolution 300 (phosphates(V)) and by titration method (ammonium, formalin method). Additionally, for solid phase analysis the X-ray fluorescence spectrometer PANalytical Magi'X PW2424 (phosphorus and metals) was used. Phases identification in a product and their quantification were done with X-ray diffractometer PANalytical XPERT PRO MPD according to Rietveld method. Using solid particles laser analyser Beckman Coulter LS 13320 product crystal size distributions (CSDs) and corresponding statistical parameters were determined. Particle shapes were evaluated based on computer-aided analysis of images from scanning electron microscope JEOL JSM 5800LV. Thermogravimetric TG and differential thermal analysis DTA tests were also done, followed by EGA analysis of gases from solid products decomposition (STA 409 PC Netzsch analyser coupled with quadrupole mass spectrometer QMS 403 C Aëolos).

TABLE I: CHEMICAL COMPOSITION OF THE CRYSTALLIZER FEED SYNTHETIC ANIMAL BREEDING WASTEWATER AND STRUVITE SYNTHESIS SUBSTRATES (MOLAR PROPORTION $\mathrm{PO}_{4}{ }^{3-}: \mathrm{Mg}^{2+} \mathrm{AS} 1: 1$ OR $1: 1.2$ )

\begin{tabular}{cc}
\hline \hline Component & Concentration (mass \%) \\
\hline $\mathrm{PO}_{4}{ }^{3-}$ & 0.208 \\
$\mathrm{NH}_{4}{ }^{+}$ & 0.451 \\
$\mathrm{Ca}$ & 0.127 \\
$\mathrm{Mg}$ & 0.053 (or 0.064$)$ \\
$\mathrm{K}$ & 0.19 \\
$\mathrm{Na}$ & 0.05 \\
$\mathrm{~B}$ & $1.62 \cdot 10^{-4}$ \\
$\mathrm{Co}$ & $0.09 \cdot 10^{-4}$ \\
$\mathrm{Cu}$ & $6.35 \cdot 10^{-4}$ \\
$\mathrm{Fe}$ & $2.20 \cdot 10^{-4}$ \\
$\mathrm{Mn}$ & $19.0 \cdot 10^{-4}$ \\
$\mathrm{Mo}$ & $0.62 \cdot 10^{-4}$ \\
$\mathrm{Zn}$ & $31.2 \cdot 10^{-4}$ \\
\hline $\mathrm{Feed} \mathrm{pH}$ & $4.2($ or 4.1$)$ \\
\hline \hline
\end{tabular}

TABLE II: CHARACTERISTIC OF SOLID PARTICLES PRODUCED FROM SYNTHETIC ANIMAL BREEDING WASTEWATER IN CONTINUOUS REACTION Crystallization, Process Temperature 298 K, PH 9 AND Mean RESIDENCE TIME OF SUSPENSION $3600 \mathrm{~S}$

\begin{tabular}{ccccc}
\hline \hline $\begin{array}{c}\text { Molar ratio } \\
\mathrm{PO}_{4}{ }^{3-}: \mathrm{Mg}^{2+}\end{array}$ & $\begin{array}{c}L_{\mathrm{m}} \\
(\mu \mathrm{m})\end{array}$ & $\begin{array}{c}L_{50} \\
(\mu \mathrm{m})\end{array}$ & $\begin{array}{c}L_{\mathrm{d}} \\
(\mu \mathrm{m})\end{array}$ & $\begin{array}{c}\mathrm{CV} \\
(\%)\end{array}$ \\
\hline $1: 1$ & 15.5 & 12.5 & 26.1 & 76.0 \\
$1: 1.2$ & 18.1 & 14.0 & 28.7 & 82.1 \\
\hline \hline
\end{tabular}

* After drying, without water washing of solid phase on a filter

Solid phase content in a product suspension $M_{\mathrm{T}} 4.3 \mathrm{~kg} / \mathrm{m}^{3}$

$L_{\mathrm{m}}$ - mean crystal size, $L_{\mathrm{m}}=\Sigma x_{\mathrm{i}} L_{\mathrm{i}}$, where: $x_{\mathrm{i}}$ - mass fraction of crystals of mean fraction size $L_{\mathrm{i}} ; L_{50}$ - median crystal size for 50 mass $\%$ undersize fraction in cumulative distribution; $L_{\mathrm{d}}-$ crystal mode size; $C V=100\left(L_{84}-\right.$ $\left.L_{16}\right) /\left(2 L_{50}\right)$, where: $L_{84}, L_{16}, L_{50}$ - crystal sizes corresponding to: 84,16 and 50 mass $\%$ undersize fractions in cumulative distribution

\section{RESULTS AND DISCUSSION}

\section{A. Crystal Size Distribution}

Statistical parameters values of CSDs representing solid products manufactured from synthetic animal breeding wastewater are presented in Table II. Under stoichiometric conditions (molar ratio $\mathrm{PO}_{4}{ }^{3-}: \mathrm{Mg}^{2+}$ as $1: 1$ ) smaller particles (mean size $L_{\mathrm{m}} 15.5 \mu \mathrm{m}$ ) and of moderate homogeneity (CV $76.0 \%$ ) were produced [10]. Dominant size of these particles was $L_{\mathrm{d}} 26.1 \mu \mathrm{m}$, and their fraction in a product was slightly more than 4 mass $\%$. 

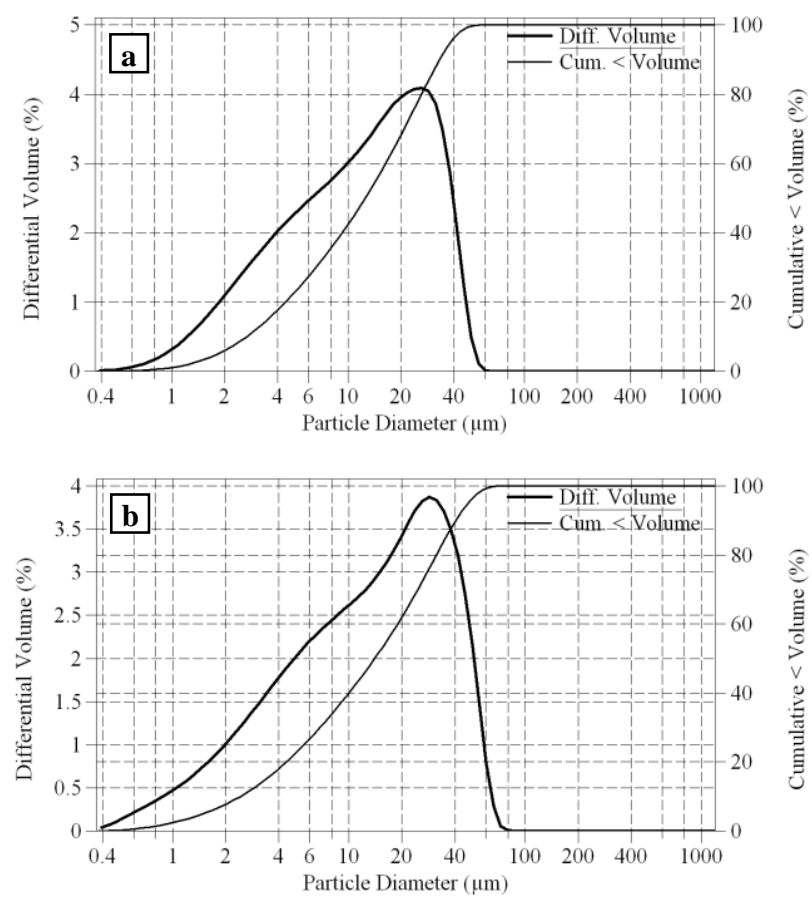

Fig. 2. Differential (left scale) and cumulative (right scale) volumetric (mass) crystal size distribution (CSD) of product particles. Molar ratio $\mathrm{PO}_{4}{ }^{3-}: \mathrm{Mg}^{2+}$ in a feed: a) $1: 1$, b) $1: 1.2$.
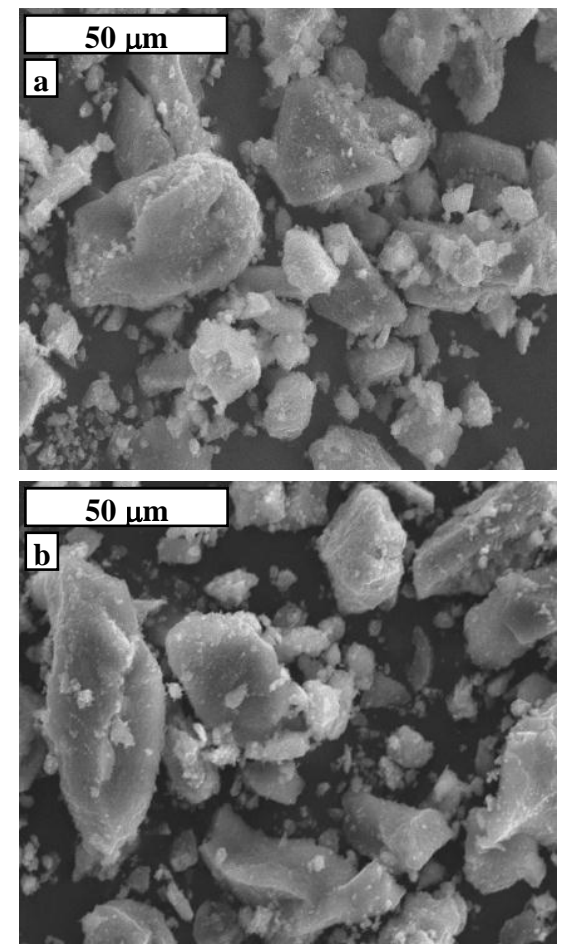

Fig. 3. Scanning electron microscope images of products (crystal size distributions and details - see Fig. 2 and Table II).

The largest particles reached $64 \mu \mathrm{m}$ only. Compared to maximal sizes of struvite crystals produced from "pure" aqueous solutions of phosphate $(\mathrm{V})$ ions $(300 \mu \mathrm{m}$ and more) [11], [12] it is not a satisfying value. Fraction of the smallest product particles, of sizes below $5 \mu \mathrm{m}$ was 22.8 vol. \%. Such large fraction considerably influenced characteristic sizes of CSD: $L_{\mathrm{m}} \quad 15.5 \mu \mathrm{m}$ and $L_{50} 12.5 \mu \mathrm{m}$. CSD of product manufactured under stoichiometric conditions is presented in
Fig. 2a, whereas microscope image of these particles - in Fig. $3 a$.

Excess of magnesium ions (molar ratio $\mathrm{PO}_{4}{ }^{3-}: \mathrm{Mg}^{2+}$ as 1 : 1.2) resulted in a more advantageous results. Mean size of product crystals increased by ca. $17 \%$, up to $L_{\mathrm{m}} 18.1 \mu \mathrm{m}$, however with higher sizes diversification: $\mathrm{CV}$ enlarged by $8 \%$, up to CV $82.1 \%$ [13].

Dominant size increased by $2.6 \mu \mathrm{m}$. The largest solids reached $78 \mu \mathrm{m}$ length. Fraction of the smallest particles (below $5 \mu \mathrm{m}$ ) was practically unmodified (22.6 vol. \%). Size distribution of product particles corresponding to magnesium ions excess, as well as microscope image of these solids are presented in Fig. 2b and Fig. 3b, appropriately.

From the ,pure" (without impurities) 0.20 mass \% aqueous solution of phosphate( $\mathrm{V})$ ions, in the comparable conditions $\left(\mathrm{PO}_{4}{ }^{3-}: \mathrm{Mg}^{2+}\right.$ as $1: 1.2$ in a feed, $\left.\mathrm{pH} 9, \tau 3600 \mathrm{~s}\right)$, struvite crystals of nearly 3-time larger mean size $\left(L_{\mathrm{m}} 48.5 \mu \mathrm{m}\right)$ and significantly more homogeneous (CV 64.6\%) were produced [12].

From the real phosphorus mineral fertilizer industry wastewater, in identical conditions, product of mean crystal size $L_{\mathrm{m}} 36.8 \mu \mathrm{m}$ and of homogeneity CV $74.7 \%$ was formed [8]. This wastewater contained phosphate $(\mathrm{V})$ ions $(0.445$ mass \%) and impurities (in $\mathrm{mg} / \mathrm{kg}$ ): $\mathrm{Al}-6.4, \mathrm{Ca}-440, \mathrm{Cu}-$ $0.25, \mathrm{Fe}-8.9, \mathrm{~K}-46, \mathrm{Ti}-0.2, \mathrm{Zn}-2.2, \mathrm{Si}-51, \mathrm{~F}^{-}-42$ and $\mathrm{SO}_{4}{ }^{2-}-703$. As it results from the comparison, mean size of these crystals was 2-time larger compared to ones produced from synthetic animal breeding wastewater. Also inhomogeneity within their sizes was smaller (CV lower by ca. $7 \%$ ). One can assume, that these differences resulted from presence and - mainly - from specific concentrations of impurities in a given process system. Net effect of impurities is usually disadvantageous [14], [15]. From SABW product of lower quality was obtained than from phosphorus mineral fertilizer industry wastewater. Some impurities in both solutions were identical, however in SABW their concentrations were many times higher. It mainly concerns calcium ions (ca. $3 \times$ higher concentration) and zinc ions $(14 \times)$. Both these ions influence struvite crystals growth disadvantageously. Calcium ions co-precipitate as phosphates [7] of considerably smaller sizes than struvite crystals, what is responsible for shift of product mean size towards smaller values. Zinc(II) ions co-precipitate, however, in a form of hydroxides, demonstrating also small particle sizes.

\section{B. Chemical Composition}

Phase composition of the products manufactured from synthetic liquid manure is presented in Table III. The composition was identified using X-ray tests (X-ray diffractometer) and confirmed with thermal analysis methods (DTA, TG, DTG) [10], [13].

Presence of struvite $\mathrm{MgNH}_{4} \mathrm{PO}_{4} \cdot 6 \mathrm{H}_{2} \mathrm{O}$ in a product was confirmed, but only in amount $<30$ mass \%. Dominant fraction turned out to be amorphous phase ( $>70$ mass $\%$ in a product) demonstrated itself as an characteristic raise in X-ray diffraction pattern's background (see Fig. 4).

After comparison of the quantitative analysis results concerning phase composition (Table III) with the inlet feed composition (Table I) one can conclude, that amorphous 
phase is mainly an hydrated form of some calcium phosphates(V) [7]. It may be supposed, that in this phase sparingly soluble hydroxides of some co-precipitating metallic impurities were also present. Thus from synthetic animal breeding wastewater solid product was experimentally obtained, which can be named as "hydrated calcium phosphate(V) with struvite additive", moreover containing also impurities (metals derived from the feed). Chemical composition of the products determined with the use of X-ray fluorescence spectrometer is presented in Table IV.

TABLE III: PHASE COMPOSITION OF SOLIDS PRODUCED FROM SYNTHETIC ANIMAL BREEDING WASTEWATER

\begin{tabular}{|c|c|c|}
\hline \multirow[t]{2}{*}{ Component } & \multicolumn{2}{|c|}{$\begin{array}{c}\text { Content (in mass } \% \text { ) } \\
\text { for molar ratio } \mathrm{PO}_{4}{ }^{3-}: \mathrm{Mg}^{2+} \text { as }\end{array}$} \\
\hline & $1: 1$ & $1: 1.2$ \\
\hline $\begin{array}{l}\text { Struvite, } \\
\mathrm{MgNH}_{4} \mathrm{PO}_{4} \cdot 6 \mathrm{H}_{2} \mathrm{O}\end{array}$ & $21.9 \pm 0.2$ & $26.5 \pm 0.2$ \\
\hline Amorphous phase & $76.5 \pm 0.5$ & $73.1 \pm 0.4$ \\
\hline Halite, $\mathrm{NaCl}$ & $1.2 \pm 0.1$ & $0.4 \pm 0.1$ \\
\hline Sylvite, $\mathrm{KCl}$ & $0.4 \pm 0.1$ & not present \\
\hline
\end{tabular}

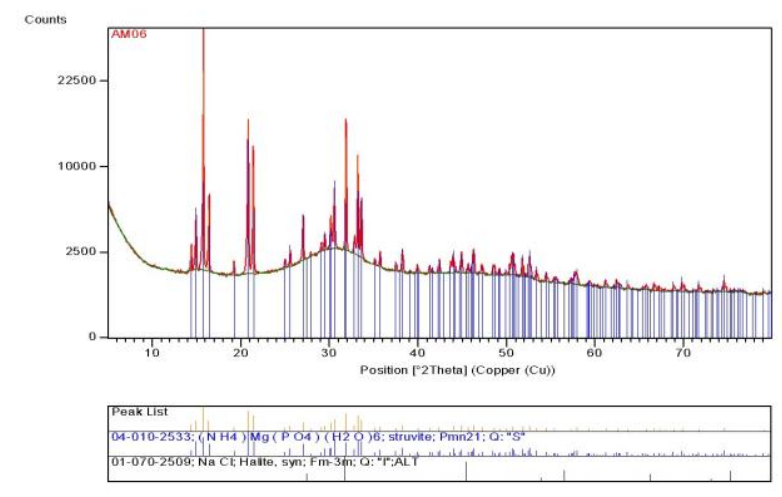

Fig. 4. The X-ray diffraction pattern of precipitated product with characteristic peaks of crystalline phases: struvite and halite. Dominant fraction of amorphous phase is visible as an characteristic background hump Process parameters: $\mathrm{PO}_{4}{ }^{3-}: \mathrm{Mg}^{2+}$ as $1: 1.2, \mathrm{pH} 9, \tau 3600 \mathrm{~s}, T 298 \mathrm{~K}$.

TABLE IV: CHEMICAL COMPOSITION OF SOLID PHASE PRODUCED FROM SYNTHETIC ANIMAL BREEDING WASTEWATER IN CONTINUOUS REACTION

\begin{tabular}{ccc}
\multicolumn{3}{c}{ CRYstallization } \\
\hline \hline & \multicolumn{2}{c}{$\begin{array}{c}\text { Content (in mass \%) } \\
\text { for molar ratio } \mathrm{PO}_{4}{ }^{3-}: \mathrm{Mg}^{2+} \text { as }\end{array}$} \\
\cline { 2 - 3 } & $1: 1$ & $1: 1.2$ \\
\hline $\mathrm{P}_{2} \mathrm{O}_{5}$ & 35.69 & 32.74 \\
$\mathrm{MgO}$ & 5.61 & 6.35 \\
$\mathrm{CaO}$ & 20.43 & 16.94 \\
$\mathrm{Fe}_{2} \mathrm{O}_{3}$ & 0.07 & 0.09 \\
$\mathrm{~K}_{2} \mathrm{O}$ & 0.47 & 0.44 \\
$\mathrm{MnO}$ & 0.41 & 0.37 \\
$\mathrm{Na}_{2} \mathrm{O}$ & 1.01 & 0.74 \\
others & 0.07 & 0.03 \\
\hline $\begin{array}{c}\text { Weight loss during drying in } \\
\text { temperature } 378 \mathrm{~K}+\text { weight loss } \\
\text { during roasting in temperature } \\
1298 \mathrm{~K}\end{array}$ & 36.24 & \\
\hline \hline
\end{tabular}

From the phase and chemical composition determination (Tables III and IV) it results, that $20 \%$ excess of magnesium ions in relation to phosphate $(\mathrm{V})$ ions affected product quality advantageously. Struvite content raised from 21.9 to 26.5 mass \% (relatively by more than 20\%) (Table III), while calcium content, considered as $\mathrm{CaO}$, decreased from 20.43 to 16.94 mass \% (Table IV). One can conclude, that magnesium ions excess in a production process of sparingly soluble phosphates(V) from (synthetic) animal breeding wastewater will favour reaction crystallization of struvite, not of amorphous calcium phosphates(V). Thus, such product can be more applicable for its further use, e.g. in agriculture [3], [9].

\section{CONCLUSIONS}

Phosphate $(\mathrm{V})$ ions were recovered from synthetic animal breeding wastewater containing 0.208 mass $\% \mathrm{PO}_{4}{ }^{3-}$ in continuous reaction crystallization process. It was concluded, that phosphate $(\mathrm{V})$ ions precipitated in a form of sparingly soluble calcium and magnesium phosphates(V). Solid product containing mainly amorphous hydrated calcium phosphate(V) (above 70 mass \%) and struvite (below 30 mass \%), as well as impurities derived from the feed was manufactured. These impurities co-precipitated, mainly in a form of sparingly soluble metal hydroxides.

Solid product demonstrated small particle sizes. Its mean size did not exceed $20 \mu \mathrm{m}$. Fraction of size below $5 \mu \mathrm{m}$ was as high as 23 vol. \%. Separation of solid phase from mother liquor was thus difficult. Vacuum filtration was long and the product after filtration still contained ca. 30 mass $\%$ of mother liquor. After drying solid phase caked and aggregated. Magnesium ions excess in relation to phosphate(V) ions influenced both phase and chemical compositions of the product advantageously. 20\% excess of these ions caused enlargement, by more than $20 \%$, of struvite fraction in a product, at the cost of undesirable amorphous calcium phosphate(V). Calcium content (recalculated as $\mathrm{CaO}$ ) decreased from 20.43 to 16.94 mass \%. Mean size of product particles increased: from $15.5 \mu \mathrm{m}$ (stoichiometric conditions) to $18.1 \mu \mathrm{m}\left(\mathrm{PO}_{4}{ }^{3-}: \mathrm{Mg}^{2+}\right.$ as $\left.1: 1.2\right)$. Application of magnesium ions excess can be thus recommended in a continuous process of phosphates(V) recovery from animal breeding wastewaters.

\section{REFERENCES}

[1] S. G. Sommer, M. L. Christensen, T. Schmidt, and L. S. Jensen, Animal Manure Recycling, Treatment and Management, Wiley, New Delhi, 2013.

[2] Y. H. Liu, J. H. Kwag, J. H. Kim, and S. C. Ra, "Recovery of nitrogen and phosphorus by struvite crystallization from swine wastewater," Desalination, vol. 277, pp. 364-369, August 2011.

[3] M. M. Rahman, Y. H. Liu, J. H. Kwag, and S. C. Ra, "Recovery of struvite from animal wastewater and its nutrient leaching loss in soil," J. Hazard. Mater., vol. 186, pp. 2026-2030, February 2011.

[4] M. M. Rahman, M. A. M. Salleh, U. Rashid, A. Ahsan, M. M. Hossain, and C. S. Ra, "Production of slow release crystal fertilizer from wastewaters through struvite crystallization-A review," Arabian J. Chem., vol. 7, no. 1, pp. 139-155, January 2014.

[5] K. S. Le Corre, E. Valsami-Jones, P. Hobbs, and S. A. Parsons, "Phosphorus recovery from wastewater by struvite crystallization: A review," Crit. Rev. Environ. Sci. Technol., vol. 39, no. 6, pp. 433-477, May 2009.

[6] J. Doyle and S. A. Parsons, "Struvite formation, control and recovery," Wat. Res., vol. 36, no. 16, pp. 3925-3940, September 2002. 
[7] E. Valsami-Jones, "Recent scientific and technical developments: calcium phosphate precipitation," CEEP Scope Newslett., vol. 41, pp. 8-15, 2001.

[8] N. Hutnik, A. Kozik, A. Mazieńczuk, K. Piotrowski, B. Wierzbowska, and $\mathrm{A}$. Matynia, "Phosphates $(\mathrm{V})$ recovery from phosphorus mineral fertilizers industry wastewater by continuous struvite reaction crystallization process," Wat. Res., vol. 47, no. 11, pp. 3635-3643, July 2013.

[9] M. Latifian, J. Liu, and B. Mattiasson, "Struvite-based fertilizer and its physical and chemical properties," Environ. Technol., vol. 33, no. 24, pp. 2691-2697, May 2012.

[10] A. Kozik, N. Hutnik, J. Podworny, A. Gerle, A. Mazienczuk, and A. Matynia, "Recovery of phosphate(V) ions from synthetic swine wastewater under stoichiometric conditions," Przem. Chem., vol. 93, no. 4, pp. 559-564, April 2014.

[11] A. Kozik and A. Matynia, "Continuous reaction crystallization of struvite under stoichiometric conditions," Przem. Chem., vol. 91, no. 5 , pp. 823-827, May 2012.

[12] A. Kozik, N. Hutnik, K. Piotrowski, and A. Matynia, "Continuous reaction crystallization of struvite from diluted aqueous solution of phosphate $(\mathrm{V})$ ions in the presence of magnesium ions excess," Chem. Eng. Res. Des., vol. 92, no. 3, pp. 481-490, March 2014.

[13] A. Kozik, N. Hutnik, A. Mazienczuk, B. Wierzbowska, K. Piotrowski, J. Podworny, and A. Matynia, "Phosphates(V) recovery from synthetic liquid manure by continuous struvite reaction crystallization process," in. Proc. 41 st International Conference of Slovak Society of Chemical Engineering, Tatranské Matliare, 2014, pp. 853-861.

[14] A. Kozik, K. Piotrowski, B. Wierzbowska, and A. Matynia, "Recovery of phosphate(V) ions from wastewaters of different chemical compositions," Progr. Environ. Sci. Technol., vol. 3, pp. 550-558, 2011.

[15] A. Kozik, N. Hutnik, K. Piotrowski, A. Mazienczuk, and A. Matynia, "Precipitation and crystallization of struvite from synthetic wastewate under stoichiometric conditions," Adv. Chem. Eng. Sci., vol. 3, pp. 20-26, June 2013.

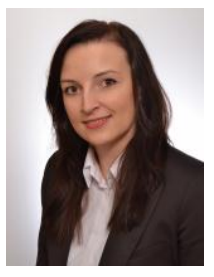

Anna Kozik obtained her M.Sc. (Eng.) and Ph.D. (Eng.) university degrees in chemical technology from the Faculty of Chemistry, Wroclaw University of Technology, Wroclaw, Poland in 2010 and 2014, respectively.

At present she is an teaching and research assistant at the Department of Technology and Chemical Processes, Wroclaw University of Technology, Wroclaw, Poland. She specializes in design, modernisation and optimisation of chemical technology processes. Her research interests include mass crystallization, wastewater treatment and phosphorus recycling. She is the co-author of 24 works published in domestic and foreign scientific journals, as well as conference proceedings.

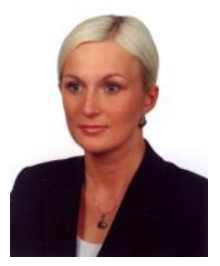

Nina Hutnik is a graduate of Faculty of Chemistry, Wroclaw University of Technology, Wroclaw, Poland. She obtained her university degree M.Sc. (Eng.) in biotechnology in 2007 and Ph.D. (Eng.) degree in chemical technology in 2011.

She is an ADIUNCT at the Faculty of Chemistry, Wroclaw University of Technology, Wroclaw, Poland. She specializes in biotechnological and chemical processes, focusing on reaction crystallization of sparingly soluble salts. She is the co-author of 64 published papers and conference proceedings.

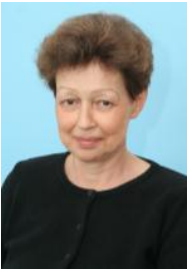

Boguslawa Wierzbowska obtained her M.Sc. (Eng.) and $\mathrm{Ph} . \mathrm{D}$. (Eng.) university degrees in chemical technology from Faculty of Chemistry, Wroclaw University of Technology, Wroclaw, Poland in 1973 and 1982, respectively.

She is an ADIUNCT at the Department of Technology and Chemical Processes, Wroclaw University of Technology, Wroclaw, Poland. She specializes in inorganic chemical technology, particularly in kinetics of mass crystallization processes. She is the co-author of about 170 published papers and conference proceedings, 5 patents and 7 industrial implementations.

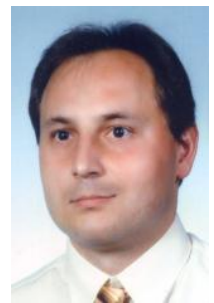

Krzysztof Piotrowski obtained his M.Sc. (Eng.). (1997) and Ph.D. (Eng.) (2002) university degrees in chemical engineering, as well as Ph.D., D.Sc. (Eng.) (2013) in chemical technology from Faculty of Chemistry, Silesian University of Technology, Gliwice, Poland.

At present he is an assistant professor at the Department of Chemical Engineering and Process Design, Faculty of Chemistry, Silesian University of Technology, Gliwice, Poland. He specializes in modeling of chemical engineering processes, especially kinetics of mass crystallization with chemical reaction. He is the co-author of 184 articles published in domestic and foreign scientific journals and conference proceedings.

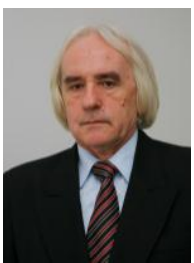

Andrzej Matynia obtained his M.Sc. (Eng.) and Ph.D. (Eng.) degrees in chemical technology from the Faculty of Chemistry, Wroclaw University of Technology, Wroclaw, Poland in 1970 and 1974, respectively. He obtained the Ph.D., D.Sc. (Eng.) degree in chemical technology and process engineering at the same University in 1996.

At present he is a full professor at the Faculty of Chemistry, Wroclaw University of Technology, Wroclaw, Poland. He specializes in inorganic technology processes and in chemical and process engineering. His scientific and engineering interests include mass crystallization from solutions, crystallizer design and process design. He is the author and co-author of more than 300 published papers and conference proceedings, 15 patents and 13 industrial implementations. 